Jelena Dimitrijević in context: early feminist travel writers of southeastern Europe

Towards the turn of the last century, the wider space of the Ottoman Empire gave rise to a number of female writers characterized by a complex and fascinating literary subjectivity. My paper focuses, in addition to Jelena Dimitrijević, on Zeyneb Hanoum, Halide Edib, and Demetra Vaka Brown. In their travel narratives, these writers, like Dimitrijević, question the dominant genre, gender, and national discoursive models. The hybrid nature of their writing, their "sincere nationalism and sincere cosmopolitism," elusive homoeroticism, irony, mimicry, and gender masquerade in their writing, their postcolonial perspective-all this creates a conductive environment for an emergence of transnational and transregional identities. I strive to show how the need of these women to traverse the physical, cultural, and symbolic spaces can be interpreted as a lasting contribution towards redefining the dominant national cultural geographies.

Keywords: Jelena Dimitrijević, nationalism, feminism, transnationalism, postcolonialism, Zeyneb Hanoum, Halide Edib, Demetra Vaka Brown

\section{Туркиње и турске теме у раној приповедној прози Јелене Димитријевић}

У својој раној књижевној фази, Јелена Димитријевић је Туркињама, односно, „турским темама“ посветила књигу поезије (Јеленине песме), роман (Нове), путописе (Писма из Ниша о харемима, Писма из Солуна) и три приповетке (Фати-султан, Сафи-ханум, Мејрем-ханум) Док су њена романескна и путописна дела углавном добро истражена, приповедна проза је остала готово непозната. Три поменуте приповетке (објављене обједињено у једној књизи 1907. године) биће предмет овог рада: о приповеци „Фати-Султан“ говориће се детаљно, док ће се на крају рада указати на садржај друге две приче како би се показала њихова тематско-мотивска сродност. Показаће се, сем културно-историјских, и књижевно-естетске вредности ране прозне фазе књижевног рада Јелене Димитријевић.

Кључне речи: рана проза, „турске теме“, Балкан 
Може се поставити питање, откуд толика уметничка „опседнутост“ЈеленеДимитријевићовомтемом, којомједебитовала и помоћу које је формирала свој књижевни израз, временом га надограђујући новим темама и мотивима. Ниш је формирао Јелену

1 Јелена Димитријевић, Седам мора и три океана: путем око света (1940). У свом последњем објављеном делу Јелена Димитријевић се такође враћа питању женских права турских жена, кроз разговор са угледном египатском феминисткињом Ходом Шарави (Huda Sha'arawi). Женским питањем бави се и у путопису Нови свет или y Америци годину дана (1934), где повремено пореди положај Туркиња у односу на Американке.

Димитријевић као књижевницу, јер се ту упознала са животима турских жена, и то у специфичним историјско-политичким околностима (ослобођење Ниша од турске власти 1878. и припајање Кнежевини Србији), али и у оквиру традиционалних облика турског живота, а посебно је значајан сусрет са „институцијом“ овог живота какав је харем, који ће свега неколико деценија касније сасвим изумрети на овом простору. Тешко је рећи да ли је посреди снажан лични, интимни занос који је као хомоеротска привлачност недвосмислено и необично храбро истакнут у њеним песмама из 1894. године. Јелена Димитријевић црпи несмањени интерес за Туркиње, скоро две деценије, занима је њихов начин живота, али је подједнако заинтересована за турску културу на нашим просторима, као за нешто потпуно другачије у односу на традиционално хришћанско васпитање. Можемо претпоставити и да је посреди социолошко-феминистичка заинтересованост за њихов дубоко ропски положај која је Јелену Димитријевић упутила ка организованом феминистичком покрету тог времена. У сваком случају, редак је пример, чак и у границама светске литературе (сем можда романа америчке књижевнице Перл Бак (Pearl Buck) о Кини), да припадница једног народа и то, парадоксално непосредно након највећих непријатељстава та два народа (српско-турски ратови од 1876. до 1878), остави тако обимно дело о женама друге конфесије, као што је то опус Јелене Димитријевић о Туркињама на Балкану. Захваљујући овоме, она је у пуној мери „интернационални писац“: топоси у њеним делима широко се простиру на све важније центре Османског царства (Солун је, на пример, главно место радње романа Нове), односно бави се турским женама од Ниша и Скопља, до Солуна и Цариграда.

И приповетаке о којима ће овде бити речи припадају том „интернационалном корпусу“, како у просторном, тако и у конфесионално-националном смислу. Наиме, иако се радња све три приповести догађа на нашем простору, она прати припаднике владајућег слоја Османске империје - Турке и Арбанасе. Они се овде могу перципирати као пример другог на Балкану, датог из перспективе домицилне српске књижевности (где се Срби, евентуално спомињу узгред, и тек „као раја“). Тим више је 
занимљиво позабавити се приповетком „Фати-султан“, која се жанровски може одредити и као новела. ${ }^{2}$

\section{Фати суптан}

Приповетка „Фати-султан“ има обележја новеле или краћег романа (148 страница) и подељена је на 18 приповедних целина (краћих поглавља). У издању из 1907. овој приповеци су придодате и две сасвим кратке приче („Сафи-ханум“, „Мејрем-ханум“) које у односу на њу заузимају занемарљив обим (укупно 28 страница). Као што се из наслова све три приповетке може приметити, главне јунакиње ових проза су жене. Урађена са највише пажње и амбиције, „Фати-султан“ доноси у српску прозу један потпуно нови свет Балкана - класу и расу владалаца на овим просторима више од четири века, које описује пред историјски крај ове владавине (средина, односно крај 19. века). По свему судећи, Јелена Димитријевић је надахнуто и под снажним утиском обрадила истинит догађај о ком јој је приповедано. Реч је о реалистичкој прози где до изражаја долази њен изразит приповедачки дар, у смени са снажним, драмским дијалозима и лирским пасажима у психолошкој функцији.

Ауторка је применила дискурс и перспективу самих османских житеља - приповедача ${ }^{3}$ као ефектан начин да се читалац in medias res уведе у радњу. ${ }^{4}$ Наратив Јелене Димитријевић усмерен је и на породицу Ахмета-хафиза, чија је ћерка Фати-султан потпуна супротност оцу. Ауторка се користи различитим приповедним техникама на самом почетку романа којима осликава простор (ефектна смена просторних планова - опис Прокупља и околине, где је Ахмету досуђен прогон), али и друштвене обичаје чаршије и прилика у граду (прве другарице, прва љубав). Како приповетка одмиче, тако полако откривамо чворни заплет ове приповедне

2 Фати-султан; Сафи-ханум; Мејрем-ханум (Београд: Штампарија „Доситије Обрадовић“, 1907.)

3 На пример, у самом уводу, обраћањем у другом лицу једнине: „Види Цариград па умри!“.

4 Овоме је послужила сцена прогона „сургуна“, преког и незгодног човека - првог имама саме Аја Софије, Ахмета-хафиза. драме у чијем центру се налазе сурови племенски закони мушкараца и који приказивањем једне женске судбине допуњује трагичну метафизику Балкана.

Лик плаховите Фати-султан, сапете патријархалним нормама и обичајима у друштву у ком се управо правила сматрају важнијим и од људског живота и изазивају читаве потресе и ланац крвне освете, а где је жена само објекат размене, разлог поседовања или окајавања образа (части), има привилегију да само начас, али у довољно битном тренутку, добије право да искаже свој став, и тим ставом (као чином личне освете), измири страсти и оде у памћење и причу. Тај тренутак када начас добије право да постане личност, превазилази њену снагу и биће, тако да скоро истовремено и она физички нестаје.

Окосницу ове драме чини љубав младе и лепе Фати-султан (у значењу: принцеза), Стамболке по рођењу, у месту очевог прогона - Прокупљу, са исто тако лепим Арнаутином, јединим сином мулаХалима Шкодарлије, Исмаил-бегом. То је љубав идеална, лирска и поетична, као са страница прозе Боре Станковића. Но, за разлику од судбина из његових прича ова љубав се потврђује и просидбом и договором обе породице око предстојећег венчања. Осећање среће која обележава догађаје око просидбе/веридбе готово да наговештава трагичан заплет и расплет.

Сличну матрицу и тематску окосницу чини и једина Јеленина „српска прича“ из истог времена „Ђул-Марикина прикажња“, где је срећа двоје вољених, на самој свадби - вољом невестиног оца, развргнута, иза чега следи хитна удаја „за недрагог“. У приповеци Фати-султан околности „развргнуте среће“ су још драстичније него у поменутој приповеци. Са фином психологизацијом кроз сцену састанка двоје заљубљених уочи свадбе, уводи се „пророчки сан“ девојке, на шта момак одговара да му је и мајка сањала нешто слично, а то све као увод у трагедију - након тог првог интимног виђења и сласти првог и јединог пољупца, и даровања ђердана (који момак жури пре свадбе да јој поклони), заљубљеног младића у повратку кући из заседе убијају непознати актери.

„Зла крв“ је пробуђена овим догађајем, што изазива коментаре чаршије. У читавој приповеци ауторка преноси ставове 
„јавног мњења“ и они, условно речено, представљају морални коректив описаних збивања, попут античког драмског хора. Ови коментари чаршије смењују класичну нарацију и постају окосница узбудљиве радње о задатој речи и части, о жртви и освети и њеном месту у ланцу крвне освете и заувек нарушене „космичке равнотеже“. Пошто чаршија „све зна“, посредовано се сугерише шта су конци сплетке која је убила несрећног младића: тада моћни Шемси-паша, уз помоћ три плаћеника најнижег реда, уклања младог Арнаутина да би омогућио женидбу свог сина са Фати-султан на коју је (због њеног порекла и сопствених амбиције „орођавања“ са Стамболијама) „бацио око“. Уцене и убиства (ускоро су и плаћеници завршили у Топлици), као уобичајени механизми власти у Османској империји, овде се додатно усложњавају: отац убијеног младића, снажни и страшни мула-Халим (који је дат рељефним описом као господар свих арнаутских фисова из рода Војњака, на које ни Турци не смеју), заклиње се да ће се осветити паши и то на карактеристичан начин: „да ће му вратити срамотом за жалост“, што је значило пресуду гору и од смрти. Старчева освета сачињава главни део приповетке, па у начелу, он постаје и главни јунак другог дела ове новеле.

Фатализам као главно обележје живота бројних женских ликова, Туркиња, карактеристично је и за јунакињу ове прозе. Нема ниједног непосредног описа њених осећања, ниједне речи коју је изговорила након што је чула за смрт свог вереника, делује као да све прима мирно, фаталистички помирена са судбином. Но, она је попут Хасанагинице, која је у народној песми такође неми учесник размирица мушких страсти преломљених преко њене властите судбине, а на које ће она имати само један лични одговор - смрт од жалости. Дакле, у истом механизму деловања женске осећајности, Фати-султан има да издржи још тежи и сложенији облик поремећених друштвених, а заправо по мушком принципу, нормираних односа. Испрошена одмах сутрадан за Шемси-пашиног сина, ${ }^{5}$ Фати-султан, коју отац (некадашње оличење самовољника који није презао од убистава, због чега је и завршио у прогону)

5 Овај догађај је био веома јасан одговор, који је већ сва чаршија знала, на питање ко је наручио убиство младог Арнаутина. одмах даје, осликана је у контрастима. Док чаршија, као морални коректив коментарише брзину њене удаје и њено „да“, дотле Јелена Димитријевић у психологизацији догађаја и личности употребљава и пејзаж, који тек у подтексту приказује право психичко стање главне јунакиње: „у небу она у једној звезди види Исмаила, своју једину љубав“, са накнадним коментаром нараторке: „...уплашена, ваљда што јој кћи много бледа, и онолико мирна. Али за што? Фати-султан је невеста, а турска невеста мора ћутати, стидети се“ (29). ${ }^{6}$ Подвучен је контраст између поједница и догађаја (припреме за свадбу) у којима је она „онолико мирна“, што је вешта најава драмског врхунца ове ситуације: усред свадбеног весеља (уочи сутрашњег доласка младожење по њу), ноћу је неко украо невесту и однео кроз прозор.

Временске прилике, какава је киша, у служби су радње и додатно појачавају дејство невиђеног скандала у чаршији. Реалистички је и опис собе, недирнуте након отмице невесте, која одражава психичку патњу жена задужених за чување Фати-султан, а поготово њене мајке. Мајке су у овој прози, и Исмаилова и мајка Фати-султан, највеће патнице и губитнице. Исмаилова мајка одмах након вести о синовљевој смрти пресвисне од туге, са речима да је за (већ увелико несрећну) судбину Фати-султан крив њен отац „коме се за грехе сад Алах свети“. Сцене у којима, тек четвртог дана по отмици, долазе Арнаути и оцу Фати-султан јављају где му се налази кћер, такође су обележене сменом наративних планова, гласа и дијалога колектива, коментарима чаршије. (Наравно, читалац ће у узрочно-последичном следу, јасно увидети да је отмичар Фатисултан њен несуђени свекар, мула-Халим).

Отклон или ретардацију у радњи, по начелима епске песме, Јелена Димитријевић уводи у следећем поглављу, дајући опширан психофизички портрет мула-Халима, другог главног јунака ове повести: не више млад, седе браде, али још увек младићког држања, огромног угледа и богатства, господар свог племена на које ни Турци не смеју, шест пута се женио, а имао је само једног сина и

6 Јелена Димитријевић, Фати-султан; Сафи-ханум; Мејрем-ханум (Београд: Штампарија „Доситије Обрадовић“, 1907), сви наводи су према овом издању. Број стране је дат у главном тексту рада у заградама одмах након цитата. 
то из последњег брака, убијеног Исмаила. Мула-Халим је смислио паклену освету, не само према непријатељу, Шемси-паши, већ је на известан начин у идеји освете заокружио и личну женску судбину Фати-Султан, венчавши се с њом. Управо оваквом осветом, у епском времену Балкана, када је срамота била гора него смрт, запечаћена је судбина и Фати-султан. Ипак, прича се још не завршава, већ драма долази до свог врхунца.

У „случај“ се умешало цело јавно мњење - по обичајном праву и сваком другом моралном кодексу, поставило се питање чија је Фати-султан? Да ли је јачи јавни чин просидбе и венчања (након подмуклог уклањања вереника Исмаил-бега), Шемси-паше, или онај, остварен отмицом (мула-Халима)? Жена је овде, као и у другим случајевима, опеваним још од песме о Бановић Страхињи, само средство (не и циљ) у чувању мушког образа, који се, ако је окаљан, мора опрати, углавном крвљу. Међутим, у овом конфликту догодиће се преседан: највиши турски представници досудили су да ће на крају сама несрећна Фати-султан морати да реши овај случај, јавно и пред званичницима.

Сложеност радње ове новеле употпуњују и сцене у ретроспективи, од тренутка када је Фати-султан доведена у Арнаутинов дом, односно у дом свог несуђеног драгог, Исмаила. У њој се наслућује сложен унутрашњи психолошки расцеп: то је посредан улазак у породицу вољеног, али у чудовишној замени (уместо Исмаила, његов отац јој је муж); то је накнадан улазак у Исмаилов живот, када овог више нема у животу (са детаљним описима његовог оружја, недирнуте собе, прострте одеће), упознавање са породичним окружењем (присуство сестре Исмаилове која је оставила породицу у граду да би била непрестано уз њу), који траје све до доласка њене мајке, а потом и родитеља „у походе“. Но, чињеница да она „само ћути“ сугерише унутарњу буру и наговештава будуће догађаје. (Прва реч након ћутње била joj je: „Мајка“). Пад Фати-султан, подсећа на „Софкин пад“ (термин Новице Петковића7) у Нечистој крви Боре Станковића, који се десио по готово истоветном механизму: Фати-султан је прешла пут

7 Новица Петковић, Два српска романа: студије о Нечистој крви и Сеобама (Београд: Народна књига, 1988.) пада, од цариградске лепотице, до девојке удате за старца (уместо своје прве љубави) и то за несуђеног свекра! Сталан подсвесни ток свести о Исмаилу, у Фати-султан рађа једну „постмортем љубав“ коју учвршћује смештеност у амбијент у коме је живео, стални поглед на његов дом, природу, његове ствари, коња, чланове породице. Временом се љубавна осећања све више фаталистички учвршћују у њој, и то у готово бизарној ситуацији у којој је постала жена његовог оца.

И повраћају је у живот полако мисли: што ће моћи овде слободно и непрестано на Исмаила мислити; што ће живети у кули у којој је Исмаил живео; што ће се шетати по вотњаку по коме се Исмаил шетао; што ће ходити кроз поље кроз које је Исмаил ходио, што ће упирати очи у високи Јастребац, у засејане брежуљке у које је Исмаил очи упирао: што ће бити близу пошумљена брега на чијем је врху Исмаилов гроб; што ће гледати Исмаилова ата...(65)

и даље:

Шушти бор....шапат је то, Исмаилов, дисање, тако јако, све јаче, као да су се скупили око ње сви ноћни дуси....Мирише копитњак и мајкина душица....дух је то, Исмаилов, мирис тако јак, све јачи, као да је ту башта онога света....Из онога сахана пало је сребро, не, олово на њене капке, очи су се склопиле...Не сања више будна. Није више бунило, ни полусан...Сан ја сад... (68)

Фати-султан је у почетку само фиктивно невеста мула-Халима (приноси му чибук, двори га, послушна је), но, када се деси и стваран брачни однос (у којем, нема сумње, Фати-султан психофизички и не учествује), долази до суптилне промене у психологизацији: она не двори више свекра, избегава заову, све више тоне у физичку болест и најзад добија грозницу. У њој се тада рађају мисли о освети, и то женској освети другима (мушким члановима заједнице, а нарочито виновнику њене личне несреће - убици Исмаила), али и целокупном сопственом удесу. Она машта о освети у строго ограниченом егзистенцијалном простору који јој је рестриктивно дат и то тако, што ће „женска глава“, управо зато што је женска глава, најжешће осрамотити убицу њеног драгог, уместо свих мушкараца у окружењу. 
Јелена Димитријевић радњу новеле поново помера ретроспективно, сада у дом Шемси-паше у Лесковцу (12. поглавље), са рељефним описом његове породице, којом доминира пашиница, која је лукава и промућурна, упућена у подмукле послове свог мужа, али и исмејана због развргнуте свадбе. Она сагледава све размере опасности која се наднела над њен дом и нарочито сина, Џафербега, за кога је њен муж намеравао да уда Фати-султан. Управо у том тренутку, стиже и вест да је мула-Халим подигао све Арбанасе у буну против паше, што је добило размере малог рата. Епизода са Манетом Кукувијом, чији портрет по срезаности и бриљантности описа подсећа на „божје људе“ Боре Станковића, има симболичну функцију да прикаже душевно стање Шемси-паше у којем се он нашао након свега.

И не сећа се да је икад досад чуо Мане Кукувију у својој махали, а сад свако вече (...) Ману су Турци, одавно, кад је био млад, момче за женидбу, украли и потурчили девојку, с којом се три године волео. Кад му је украли, разболео ce, а кад му она поручила да није човек него жена кад не може од Турака да је отме, полудео. Из Власине је, а никад од тада није у Власини, него тумара, завлачи се по шуми у дупље дрвећа и виче, дању, у пролеће, с кукавицама, а ноћу, увек, с кукумавкама. Понекад дође у Лесковац, где му је девојка потурчена, па дању тумара турским махалама као да је тражи, и ћути; а ноћу виче. Двадесет осам година од то доба, од његове девојке само пепео, ваљда, јер је умрла још прве године пошто су је потурчили, а он је још тражи, још кука за њом и прети Турцима. Кад је најлепша месечина највише виче, а тишином разлеже се његов глас далеко, језа подузима свакога који га чује. Турци, враћајући се из каване, обилазе га; не грде га што иде ноћу без фењера као хајдук, грехота; не осврћу се на његове претње, боје се.

Паша га досад, како му се чини, никад није чуо у својој махали; а сад, има недеља дана, сваку ноћ, баш око поноћи, кад се сам слободи, и развесели. Јежи му се кожа, и што је у души зидао за неколико сата, то Маном глас обори за цигли један тренутак. С виком Мана Кукувије причује му се и мулине речи: ти си мени крви дужан. (88-89).
Сусрет двојице сада крвних непријатеља, Шемси-паше и мулаХалима, у Прокупљу ${ }^{8}$ кроз епски дијалог (позив на мегдан мулаХалима) завршава се неочекиваним пашиним предлогом да Фатисултан дође „на испит“, то јест, да она сама одлучи за кога ће се удати, на шта мула Халим, зачудо, пристаје. Договор је пропраћен вештом драмском сценом и фином психологизацијом личности: паша је срећан („зна се за кога ће!“), мула-Халим је одједном „стварно старац“, док бесни Арнаути, уместо паше, сада хоће да убију „кучку“.9 Свакако да кулминацију ове радње представља 16. поглавље, у коме је описан преокрет у вековима окамењеним и нормираним односима једног друштва. Овде се показује смисао ауторке за масовне сцене када приказује Арнауте који су опколили кућу где ће бити испит. Код Фати-султан наступа спољашњи преокрет: одједном се „само смеје“, ведра је, а у себи је потпуно рашчистила и осмислила час и начин освете на предстојећем испиту. ${ }^{10}$ Свакако, кулминацију представља час испита у општинској кући. Фати-султан ћути и не одговара на постављено питање да ли хоће да се уда за Џафер-бега, Шемси-пашиног сина. Сцена доживљава климакс када на три пута постављено исто питање: да ли хоће да се уда за мулу-Халима, она пристаје, јер већ у утроби носи „мулино чедо“. Ипак овај пристанак прати њена следећа порука коју је изговорила као жена-личност први пут на јавном месту, загрцнуто и немушто, у трећем лицу. Порука је очигледно дуго смишљана и са посебном поентом:

Кажи селам Шемси-паши, џелату: оће да има чедо....од муле....Фати-султан. И кажи селам Шемси-паши, џелату: непуштена кадуна његовог сина од другога....чедо. И кажи селам Шемси-паши, џелату: данас му је прилепила блато на чело и ударила катран на лице Исмаилова невеста... (119).

Али, са том осветом и мисијом, која превазилази њен крхки физички састав и сам њен живот већ је о концу. Болесна од туберкулозе, изложена душевним потресима, у свету је, нама можда данас несхватљивом, где се од неостварене љубави заиста умире. Ово

8 Овде је посебно упечатљив опис до зуба наоружаних Арнаута, који јашу кроз чаршију.

9 Из свега овога се јасно види став да се женско посматра као оличење свих невоља и срамоте, иако је само предмет њихове расправе.

10 Фати-султан се вратила у свој дом и добила „да размишља читаву недељу дана“. 
је опште место за јунакиње Туркиње у прози Јелене Димитријевић, што се уклапа у начин на који се балкански фатализам приказује у књижевности, без обзира на конфесије, како у нашој народној лирици, тако и у делима књижевника с краја 19. и почетка 20. века (пре свих Боре Станковића). Тако несрећно вене и умире непосредно по удаји „за недраго“ и невеста у Писмима из Ниша о харемима, од туге и због издаје у љубави (која се манифестује као туберкулоза) умире млада и Емир-Фатма из романа Нове. Продужетак судбине и агоније Фати-султан уобличен је у крај ове сторије: пошто се осветила за његовог сина, Мула-Халим је „отпушта“, то јест, она остаје у својој родној кући у Прокупљу („и никад од тада не виде муле“). И док јавно мњење благосиља њен говор („У џенет ћеш Султанијо. Голем си севап учинила!“), она у родитељској кући, после побачаја, има само још толико времена да умре. У наглашеној поетизацији простора и пејзажа (смене годишњих доба, зиме пролећем), уобличена је психологија Фати-султан - њена заправо вечита, фаталистичка верност Исмаил-бегу, њеној првој и једној љубави, кога она почиње да виђа у сну, у халуцинацијама, у цвећу, са жељом да му се придружи, са врло прецизним навођењем да ће то бити „на Ђурђев-дан“ када ће он доћи по њу. Завршница ове прозе (испунило се предосећање главне јунакиње да ће умрети на ђурђевдански уранак), по завршним тоновима налик је на народне баладе, где се често после смрти јунака користи флорална симболика: често се приказује мноштво биљне орнаментике на гробу заљубљених, којима се симболички продужава вечна енергија њихове неостварене љубави, ${ }^{11}$ односно осећање исказано формулативним стихом: „Ђул мирише, Омерова душа.“12

Уметак, тј. 17. поглавље, на јавној, мушкој сцени, описује покушај мирења Шемси-паше, веома уплашеног крвном осветом, који се саветује са паметном и лукавом пашиницом, и молбом упућеном скадарском паши да посредује и тражи „опроштај крви“

11, „..Из Омера зелен бор никао , / Из Мериме зелена борика: / борика се око бора вила / кано свила око ките смиља.." (Балада „Смрт Омера и Мериме“, Вук Стефановић Караџић, Српске народне песме I (Београд: Просвета, 1954), 345.

12 Овим стихом-синтагмом као кључном поентом, завршава се и студија Хатиџе Крњевић, „Смрт Омера и Мериме - „омиљеница“ Лазе Костића“. В. Živi palimpsesti ili o usmenoj poeziji (Beograd: Nolit, 1980), 109-121. од мула-Халима. Сусрет два стара пријатеља је моменат када, у источњачком маниру, Јелена Димитријевић у дијалог уводи и једну параболу о пријатељству, којом се заправо мула-Халим, одриче и овог пријатеља (јер је дошао да га помири), али „прашта крв“ паши, но са далекосежном изреком: „и зна причу Јарац и Вук... Кад је оно ударио рогом јарац вука, опростио му вук, али нису вучићи“ (133). Сложени рукавци свих догађаја, које су покренуле жестоке страсти ни овим нису завршене: и поред „опроштаја“ добијеног од Арнаутина, Шемси-паша једног јутра тајно, у каравану, бежи из града и настањује се у Стамболу (Цариграду). Пун смисао ове приповести дат је у сасвим кратком епилогу којим Јелена Димитријевић заокружује ову повест: да је у Старој Србији, у Косовској Митровици, „пре десетину година“један млади Арнаутин из рода Војњака, убио младог Цариграђанина, Хасан-беја, „а сваки знаде да му млади ћитаб не бејаше ништа учинио“. Тек се накнадно сазнало да је млади ћитаб био праунук Шемси-паше, а унук његовог сина, након чега ауторка додаје: „За крв сина поглавара војњачког није узета крвнина, те је освећена крвљу, и то после пола столећа, и више“ (148).

По свему судећи, реч је о вредном књижевном делу Јелене Димитријевић, које је до сада углавном изостављано из проучавања њеног књижевног опуса, па тако и из историје српске књижевности у целини. По овоме, Јелена Димитријевић, уз Григорија Божовића, и у наше време Данила Николића, у српску књижевност уводи и друге конфесије са вечито немирног тла Балкана, рељефно приказујући како њихову фолклорну традицију, тако и психолошке карактеристике, чиме на књижевни начин драгоцено допуњује антрополошку слику прошлости наших простора.

Мула смућен, Арнаути гори него пре, љути што им мула иде Шемси-паши, крвнику, прете и ударају коње стрменом сваки час; а кад дођу близу каквог дрвета, опале, неки, из пушке, те се стресе снег и прхне преплашено јато врана, гачући (96).

Или:

Пред кулом су Арнаути, не као до сада из неколико села, већ из свих, и што је год за пушку дошло је, па све оружано до зуба, све шкрипи зубма, све тајно прети паши, највише 
несрећној Фати-султан. Зима. Сви су увијени у јапунџа. Нестрпљиви. (106).

Ако се на простору Југа (Старе Србије) у текстовима Јелене Димитријевић помињу и Срби, то је више узгредно, ретко и према датостима саме приче: најчешће као обезвлашћена раја у сцени као што је следећа:

Сутра-дан угледаше Арнаути кроз своја до пре неки дан тучна поља, кроз ливаде тахтариван, то јест носила, као собицу неку, од дасака, притврђену на две мотке, коју носе четири чифчије бекри Ахмеда хафуза, раја турска, Срби, опасани ликом; а дванаест крај носила иду, за смену и по двојица их са стране придржавају, да се не накрећу (...) У тахтаривану је мајка Фати-султан ханумина. (61),

или кроз сцену свакодневне обесправљености православних хришћана, као типичне слике вековног ропства:

Кад зађоше у српску махалу, и мула бејаше далеко, отвори се једна трошна капија искрпљена парчадма тенећке, и асуре, и истрча из дворишта једна сиромашна жена, Српкиња, наричући за сином, и скиде шамију с главе, гологлава проклињаше арнаутску силу и турску обест. „Луда! Луда“ узвикнуше неки (...) и обиђоше је; а други, ђаволови синови, окренуше коње к њој, да је прескоче... Прегазише је, па продужише пут, не осврнувши се... Кад се последњи пут побунише Арнаути, убишејој сина, њену милост и хранитеља кириџију, који бејаше пошао у Ниш с топличким јабукама.

Мула је Арнаутин, али да се обазре и виде шта учинише ови ђаволови синови са женском главом и ојађеном мајком, не би им се прошло наште срца. (97)

Но, врло је занимљива једна интерполација: у ноћи Исмаиловог убиства, док га брижни родитељи ишчекују после састанка с драгом, Јелена Димитријевић доноси и овакав пасаж:

зачу се кроз ноћну тишину јејина, тица злослутница; зајецаше струне на гуслама од ветра кроз незатворене капцима прозоре; потресе се покривена паучином икона Светога Николе на тавану мула-Халимове куле; ваљда се потресе сам светитељ с несреће потомака оних што су се пред њим часним крстом крстили и служили му службу свету.. (20)
Ову сцену не можемо тумачити другачије, већ као сећање на Велику Сеобу, под патријархом Чарнојевићем, што опет, имплицира време досељавања мула-Халимовим предака (Арбанаса из Албаније) на простор Топлице, дакле крајем 17. или почетком 18. века, у кулу неког имућнијег Србина, који ју је у сеоби напустио, на чијем тавану су затечени и остављени непотребни артефакти бивших становника, хришћанских власника.

Треба, такође, напоменути, да је тема ове новеле, три године пре Нечисте крви Боре Станковића, антиципирала, додуше са сасвим других позиција и из сасвим другачијих узрочно-последичних односа, однос свекра и снахе, као прастаро, специфично антрополошко патријархално право, веома присутно и на Балкану (посезање за правом „прве брачне ноћи“ свекра уместо сина, за невестом), где је снаха, у мушком патријархалном домицилу, предмет размене и намиривања добара, и сексуалних прохтева. Док је у литерарној обради та тема код Боре Станковића поетизована кроз Софкину лепоту, која иницијално у будућем свекру, газда-Марку, изазива еротску жудњу коју он ипак савлада, у случају Фати-султан, свекар је „силом прилика“ кроз строго детерминисане законе (освета у виду „срамоте за жалост“) у суштини еротски незаинтересован за снаху, иако у почетку само у фиктивном браку, ипак посегнуо за правом „прве брачне ноћи“ (које Јелена Димитријевић посредно објашњава, да се „човек заборавио“). Тиме је пропаст несрећне невесте - што је аргумент који је она и јавно изнела, осујетивши и осрамотивши тиме читаву Шемси-пашину намеру - само убрзана. По тим дубинским потресима, законима крви и тла на Балкану, мала је разлика међу конфесијама, али се „мушка срамота“ у оба случаја плаћа главом (Марко је сам убрзао своју смрт, а код Албанаца, право је (непотребно) искоришћено, док истовремено беса и освета остају активиране чак након четири генерације, да би се ипак, на потпуно недужном, извршиле).

Стога је проза „Фати-султан“ Јелене Димитријевић у овом случају, значајан прилог (психосоцијални, антрополошки, књижевни) духовној историји патријархалних обичаја и норми на Балкану формираних у последњих неколико векова, али и важан показатељ метафизике зла и крви, насиља на овом простору, 
ухваћен у једном карактеристичном тренутку, а који у доброј мери може да антиципира и садашњу неуралгичност овог простора - бивше Османске империје са мешавином веома сложених конфесионалних, психосоцијалних и националних група и народа - дајући сложен, упечатљив и згуснут снимак нарави на Југу Србије, преломљени кроз једну (трагичну) женску судбину.

\section{Сафи-ханум, Мејрем-ханум}

Остале две прозе „Сафи-ханум“ и „Мејрем-ханум“ придодате новели „Фати-султан“, представљају два реалистичка исечка (лична доживљаја), који се такође у тематско-стилском смислу уклапају у „турску прозу“ Јелене Димитријевић. Жанровски краће од приповедака, насловима, такође, концентрисане на женске ликове, ове прозе су засноване на једном догађају („Сафи-ханум“) ${ }^{13}$ или анегдоти („Мејрем-ханум“). Треба нагласити да обе прозе описују карактеристичне јавне (затворене) скупове-седељке турских жена: у првој прози то је једно вече у харему у Скопљу, на седељци код богате Али-пашинице (са свим женским званицама звучних титула, пореклом од Цариграда, Анадолије, са Родоса и Крита, све до Солуна и Сарајева, обучених, како пише Јелена Димитријевић a la franga), док је у другој то једно заједничко „бањање“ или купање у Нишкој бањи, свих главних турских госпођа из Ниша, заједно са својим слушкињама и робињама („Мејрем-ханум“). Снимци начињени фотографским оком Јелене Димитријевић, раскош и сјај Истока, дати и кроз управни говор ових јунакиња, откривају да је ауторка непосредни сведок у другој причи, дајући то и у форми једног личног доживљаја („Мејрем-ханум“). Док је у првој причи, међу свим званицама издвојена једна млада жена, Сафи-ханум, по ономе што ће и симболиком свог имена (у значењу: Чиста) учинити дарујући тајно сиротој везиљи ${ }^{14}$ најскупоценије што има - златни мерџан око врата, дар свог мужа са првог виђења, а све за здравље свог тек рођеног синчића. Ово доброчинство, у облаку дима и

13 „Сафи-ханум“ би по основној теми и поруци могла носити наслов и „Велико доброчинство“.

14 Везиља продаје вез своје кћерке за свадбу како би исплатила кирију. загрејаних жена нико не види, сем једне „хануме“ која овакав поступак благосиља.

У другој прози реч је готово о реалистичкој сцени - исечку, који је скоро може бити „органски“део Писама из Ниша охаремима. Уводећи кроз своје аутобиографско ја и себе у приповест, Јелена Димитријевић, у опису бањања и уживања Туркиња у води, не без еротских конотација, даје само један карактеристичан доживљај: спавање са породицом Мејрем-ханум (друге главне јунакиње по којој је назвала причу) где усред ноћи, са њеним кћеркама присуствује њеном „ноћном читању“ у сну молитве на арапском језику, за шта накнадно открива чудесан механизам и навику „одуживања“ верских обреда и у сну, ако то не стигне за дана! У форми анегдоте, ова прича плени живописношћу стила и језика Јелене Димитријевић, у којима се још једном ишчитава необична фасцинираност турским женама, њиховим начином живота, институцијама (харема), навикама и духовном светом у целини.

\section{Закључак}

Рана прозна фаза Јелене Димитријевић фокусирана је на Туркиње и „турске теме“. Кроз приповест о Фати-султан, која има форму и одлике мини романа или новеле, уочене су, сем наративних врлина Јелене Димитријевић и иновативност теме (писање о другом, тј. Турцима и Арбанасима на тлу Јужне Србије половином и пред крај 19. века, а током владавине Османске империје), као и избор главне јунакиње - жене - која у сложеном сплету друштвених околности израста у (трагичну) главну јунакињу. Заједнички услови живота у Османској империји условили су низ паралела са књижевним светом Боре Станковића (на које је тек указано), али и на нашу фолклорну традицију (пре свих баладе, „Хасанагиница“, затим „Смрт Омера и Мериме“), најзад и специфично уочена антрополошко-патријархална обичајна норма на релацији снахасвекар оличена у праву „прве брачне ноћи“. По свему судећи, реч је о запостављеном и вредном прозном и реалистичком остварењу Јелене Димитријевић, у српској књижевности, на самом почетку 20. века. 


\section{ПИТЕРАТУРА}

ИЗВОРИ

Димитријевић, Јелена. Фати-султан; Сафи-ханум; Мејрем-ханум. Београд: Штампарија „Доситије Обрадовић“, 1907.

Димитријевић, Јелена. Нове. Београд: Српска књижевна задруга, 1912.

Димитријевић, Јелена. Седам мора и три океана: путем око света. Београд: Државна штампарија Краљевине Југославије, 1940.

Димитријевић, Јелена. Писма из Ниша о харемима (предговор Слободанка Пековић), Београд, Горњи Милановац: Народна библиотека Србије, Дечије новине, 1986 (фототипско издање).

Димитријевић, Јелена. Писма из Солуна (прир. В. Бошковић, Д.Аничић), Лозница: Карпос, 2008 (на српском и грчком језику).

Станковић, Бора. Нечиста крв. Београд: издање пишчево, 1910.

Стефановић Караџић, Вук. Српске народне пјесме; женске. Београд: Просвета, 1953.

\section{СЕКУНДАРНА ПИТЕРАТУРА}

Krnjević, Hatidža. Živi palimpsesti ili o usmenoj poeziji, Beograd:Nolit, 1980.

Петковић, Новица. Два српска романа: студије о Нечистој крви и Сеобама. Београд: Народна књига, 1988.

\section{Slavica Garonja Radovanac \\ Faculty of Philology and Arts}

University of Kragujevac

Turkish women and turkish topics in the early prose of Jelena Dimitrijević

In her early literary phase, Jelena Dimitrijević dedicated one poetry collection (Jelena's Poems), two novels (Letters from Nis on Harems, Nove), one travelogue (Letters from Salonica) and three short stories (Fatih-Sultan, Safi-Khanum and Meyrem-Khanum) to Turkish women, that is, "Turkish topics." While her novels and travelogues have mostly been well researched, her short stories remain almost unknown. The topic of this paper will be the three aforementioned short stories (published together in one book in 1907). We will discuss Fatih-Sultan in great detail, while we will touch on the content of the other two short stories at the end of the paper in order to demonstrate the similarity of themes and motives. Aside from cultural and historical values of the early prose phase of Jelena Dimitrijević's literary work, we will also present its literary-aesthetic values.

Keywords: early prose, "Turkish topics", the Balkans

\section{9) Спектар родних трансформација у Писмима из Ниша о харемима Јелене Димитријевић}

У овом раду се анализира контроверзан уметнички сегмент путописног текста Писма из Ниша о харемима (1897) Јелене Димитријевић (1862-1945). Проучавани су следећи елементи: представа харемске културе и однос према женској сексуалности и лезбејској пракси у муслиманском друштву. На примерима из текста, демонстрира се на који је начин Јелена Димитријевић демистификовала харемски ентитет.

У закључним разматрањима истиче се да је књижевница (у својем путописном извештају) открила женску поткултуру која симболизује отпор према мушкој доминацији на социјалном, културном, али и на сексуалном плану. Указали смо да турски однос према сексуалности, као концепту расплинутом између биолошког, друштвеног и физичког, функционише на неколико нивоа: кроз теоријско поштовање религиозних и моралних закона, али и кроз животну праксу која се заснива на моделирању ових правила, практиковањем хомосексуалних/лезбејских односа, што је последица ригидног система, али уједно укључује потпуну слободу у истраживању и померању граница сексуалног задовољства. Иновативном родном експертизом табуизиране женске сексуалности, Јелена Димитријевић се приближила савременом интернационалном феминистичком дискурсу.

Кључне речи: феминистичка теорија, родне улоге, алтеритет, харемска књижевност, трансвестија, трансродност, другост, лезбејство 